\title{
Plasma Nitriding of ISO 5832-1 Stainless Steel with Intermittent Nitrogen Flow at $450^{\circ} \mathrm{C}$
}

\author{
Ricardo Fernando dos Reis ${ }^{\circledR}$ [, Paulo Gabriel Heity Mori da Silva ${ }^{a}$, Rodrigo Lupinacci Villanova ${ }^{a}$, \\ Andrey Matheus Vianna ${ }^{a}$, Euclides Alexandre Bernardelli * (D) \\ anniversidade Tecnológica Federal do Paraná - UTFPR, Laboratório de Plasma, Departamento \\ Acadêmico de Mecânica-DAMEC, Dep. Heitor A. Furtado, 5000, Ecoville, CEP 81280-340, \\ Curitiba, PR, Brasil
}

Received: September 3, 2019; Revised: December 12, 2019; Accepted: January 7, 2020

\begin{abstract}
ISO 5832-1 stainless steel specimens were plasma nitrided at different nitrogen potentials. The main goal was to obtain the S-phase with different nitrogen concentrations and free of chromium-based precipitates. The control of nitrogen potential was made by pulsing the gas at predetermined times: 10/10, $05 / 15,02 / 18$, and $01 / 19$, where the numbers represent the time in minutes that the nitrogen flow was kept on/off, respectively. For all pulsing conditions, the nitriding was carried out at $450^{\circ} \mathrm{C}$ for 2 hours. After nitriding, specimens were characterized by means of optical (OM) and electron microscopy (SEM), energy-dispersive spectroscopy (EDS), X-ray diffraction (XRD) and microhardness. Results show that the nitrided layer thickness decreases with decreasing times of nitrogen pulse, and that lower times of nitrogen flow lead to lower precipitation of chromium nitrides. It can be thus concluded that the use of intermittent nitrogen flow is an alternative to control the nitrided layer in terms of thickness, hardness, and the amount of nitrogen present in phase $\gamma_{N}(S-p h a s e)$.
\end{abstract}

Keywords: Plasma nitriding, S-phase, ISO 5832-1, Stainless steel, Nitrogen potential.

\section{Introduction}

The high corrosion resistance of austenitic stainless steels makes them widely used in the industry. However, in order to further increase its applicability by improving localized corrosion resistance and tribological properties, some techniques regarding introduction of nitrogen in solid solution have been employed ${ }^{1-9}$. Among those techniques, plasma nitriding has been largely used.

Plasma nitriding at temperatures close to $450{ }^{\circ} \mathrm{C}$ or above favors the formation of chromium precipitates $\left(\mathrm{Cr}_{\mathrm{x}} \mathrm{N}_{\mathrm{y}}\right)$, resulting in higher surface hardness and, consequently, improved wear resistance of those steels. On the other hand, the formation of such chromium-based nitrides causes a reduction in the amount of chromium dissolved in the steel matrix, impairing its corrosion resistance, since the formation of the characteristic passive layer becomes more difficult ${ }^{10,11}$.

Since the majority of beneficial effects of nitrogen is associated to its presence in solid solution ${ }^{12}$, precipitation of nitrides should be avoided during plasma nitriding. One way of achieving this is by lowering the process temperature to about $400{ }^{\circ} \mathrm{C}$, in order to obtain a nitrided layer constituted mainly by a metastable, supersatured nitrogen phase called expanded austenite $\left(\mathrm{\gamma}_{\mathrm{N}}\right)$, or S-phase. In this phase, the austenite fcc lattice is expanded in relation to its original size due to the presence of nitrogen. The increase in the nitrogen concentration in the austenite also causes an increase in stacking faults, introducing a high level of compression residual stresses within the lattice with consequent surface hardening ${ }^{13}$. Volumetric expansion of the fcc lattice associated to the nitrogen supersaturation is observed by both shifting to slower angles $2 \theta$ and broadening of X-ray diffraction peaks.

*e-mail: ebernardelli@utfpr.edu.br
Hence, the use of plasma nitriding in applications where corrosion resistance is an issue is limited to processes made at low temperature, where the formation of S-phase $\left(\mathrm{V}_{\mathrm{N}}\right)$ is the only transformation that occurs at the material surface ${ }^{1,14,15}$. However, nitrided layers obtained at these conditions are, in general, very thin ${ }^{9}$. Some authors ${ }^{16,17}$ also observed that the high hardness of the layer, caused by the high compression stress level, may lead to nucleation of cracks. In this regard, with the aim of reducing brittleness, Sphair ${ }^{18}$ studied the influence of the nitrogen potential control, made by means of intermittent nitrogen flow during plasma nitriding, upon the amount of nitrogen into expanded austenite. She observed that it is possible to control the degree of expansion of S-phase.

Considering the work of Sphair ${ }^{18}$, which demonstrated the possibility of controlling the amount of nitrogen in $\mathrm{\gamma}_{\mathrm{N}}$ phase, and considering the works of Yazıcı et al. ${ }^{19}$ and Mingolo et al. ${ }^{20}$, which demonstrated that chromium nitride precipitation is influenced by the amount of nitrogen in $\gamma_{N}$ phase, the possibility of controlling the precipitation of chromium nitrides, even for process temperatures around $450{ }^{\circ} \mathrm{C}$ or higher, is considered. That could be achieved by altering the nitrogen potential with the use of intermittent nitrogen flow during plasma nitriding.

Thus, the aim of this work was to verify the feasibility of nitride austenitic stainless steel (ISO 5832-1) at $450{ }^{\circ} \mathrm{C}$, where the formation of chromium nitrides precipitates $\left(\mathrm{CrN}\right.$ or $\left.\mathrm{Cr}_{2} \mathrm{~N}\right)$ is known to occur, with the use of intermittent nitrogen flow, in such a way that thicker layers than those formed at lower temperatures could be obtained without precipitation of chromium nitrides. 


\section{Experimental Procedures}

The chemical composition of the material use in this work, an ISO 5832-1 stainless steel ${ }^{21}$, is shown in Table 1. Cylindrical specimens, $15.0 \mathrm{~mm}$ in height, were obtained from a bar with $15.8 \mathrm{~mm}$ in diameter. After cutting the samples with appropriate cutoff wheel, they were ground with emery paper, and polished with $1 \mu \mathrm{m}$ alumina suspension. The starting microstructure of specimens was fully austenitic, with a hardness of $216 \pm 7 \mathrm{HV}$. Before nitriding, samples were ultrasonically cleaned for 20 minutes in ethanol, in order to remove contaminants from previous preparation steps.

After cleaning, specimens were plasma nitrided in a pulsed DC glow discharge in two consecutive stages. The first stage corresponded to sample cleaning by cathodic sputtering, and the second to the plasma nitriding process itself.

The cleaning sputtering was carried out to remove the oxides comprising the external passive layer, which, as mentioned, is a characteristic of stainless steels. This cleaning stage was carried out with hydrogen (50 sccm) and Argon $(100 \mathrm{sccm})$ for 30 minutes, under the pressure of $266.64 \mathrm{~Pa}$ ( 2 Torr), and at $300{ }^{\circ} \mathrm{C}$. The nitriding process was performed in five different processing conditions. For all of them, the following parameters were employed: total time of 2 hours, temperature of $450{ }^{\circ} \mathrm{C}$, total gas flow of $200 \mathrm{sccm}$ and pressure of $533 \mathrm{~Pa}$ (4 Torr). In one processing condition (2C), nitrogen flow was kept continuous during nitriding, with no changes in the atmosphere, and for the other conditions (2PXXYY), the nitriding atmosphere varied with time, where XX denotes time with nitrogen flow (nitrogen on) and YY denotes time without nitrogen flow (nitrogen off), in periods of 20 minutes that were repeated 6 times within the 2 hours of treatment. Processing conditions are detailed in Table 2, and the samples ideintification scheme is shown in Figure 1. The atmosphere composition was based on the work of Sphair ${ }^{18}$, where low temperature $\left(400^{\circ} \mathrm{C}\right)$ nitriding of ISO 5832-1 steel was carried out with the same processing conditions used in the present work.

\section{C \\ Continuous nitrogen flow Treatment time $(\mathrm{h})$}

After plasma nitriding, specimens were cooled down to $300{ }^{\circ} \mathrm{C}$ under $\mathrm{H}_{2}$ plasma in order to minimize oxidation risks, and then cooled under vacuum to room temperature. For each treatment condition, four specimens were characterized.

For characterization, specimens were longitudinally cut and mounted in high hardness resin (Bakelite) to preserve borders. The cross-sections obtained were prepared with an adequate metallographic process to investigate the morphology, thickness, and microhardness profiles of the resulting layers. The morphology evaluation of the nitrided layer was carried out by means of optical microscopy (OM) and scanning electron microscopy (SEM). Prior to microscopic observation, all samples were electrolytically etched with Marble's reagent ( $\left.1 \mathrm{~g} \mathrm{CuSO}_{4}, 5 \mathrm{~mL} \mathrm{HCl}, 5 \mathrm{~mL} \mathrm{H}_{2} \mathrm{O}\right)$. Thickness measurements of the nitrided layer were made with an image analyzer software (Image Pro-Plus) from micrographs obtained by means of optical microscopy. Microhardness measurements (Vickers indenter) were carried out with the use of a microhardness tester Shimadzu model HMV2 and load of 100 gf. X-ray diffraction was used to identify the phases present in the nitrided layer, and a Philips diffractometer was used to obtain the diffractograms with the following parameters: $\mathrm{Cu} k \alpha$ radiation $(\lambda=1.54060 \AA)$, current of $30 \mathrm{~mA}$, voltage of $40 \mathrm{kV}, 2 \theta$-scan step of $0.05^{\circ}$, scanning angle range of 20 to $120^{\circ}$, and scan rate of $0.05^{\circ} / \mathrm{s}$. The measurements were performed at a $10^{\circ}$ angle of incidence. Energy dispersive X-ray spectroscopy (EDS) was used for qualitative chemical analysis at different areas of the specimens.

In order to estimate the nitrogen concentration $\left(\mathrm{C}_{\mathrm{N}}\right)[\mathrm{at} \%]$ in the specimens, we used the variation in austenite lattice parameters before $(\mathrm{a} \gamma)[\AA]$ and after $\left(\mathrm{a} \gamma_{\mathrm{N}}\right)[\AA]$ nitriding. Analysis was based on the shift of the austenite peak $(2 \Theta=43.47)$ corresponding to the crystallographic plane (111). The nitrogen concentration value for the different treatment conditions was calculated with Picard's Equation $1^{13}$, using $0.0078[\AA /$ at $\% \mathrm{~N}]$ as the value for Vegard's constant

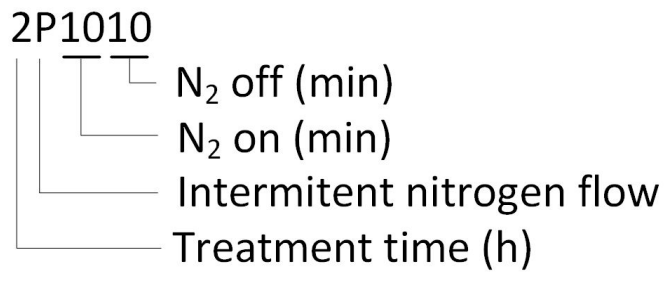

Figure 1. Processing conditions identification scheme (example).

Table 1. Chemical composition of ISO 5832-1 austenitic stainless steel (wt\%).

\begin{tabular}{cccccccc}
\hline $\mathrm{C}$ & $\mathrm{Mn}$ & $\mathrm{Si}$ & $\mathrm{Cr}$ & $\mathrm{Ni}$ & $\mathrm{Mo}$ & $\mathrm{N}$ & $\mathrm{Fe}$ \\
\hline 0.017 & 1.750 & 0.350 & 17.800 & 14.300 & 2.760 & 0.077 & Balance \\
\hline
\end{tabular}

Table 2. Summary of processing conditions

\begin{tabular}{|c|c|c|c|c|c|}
\hline \multirow{2}{*}{ Condition } & \multirow{2}{*}{$\begin{array}{l}\text { Nitrogen flow } \\
\text { on (min) }\end{array}$} & \multirow{2}{*}{$\begin{array}{l}\text { Nitrogen flow off } \\
\text { (min) }\end{array}$} & \multirow{2}{*}{ Repetition } & \multicolumn{2}{|c|}{ Atmosphere } \\
\hline & & & & With $\mathrm{N}_{2}$ & Without $\mathrm{N}_{2}$ \\
\hline $2 \mathrm{C}$ & 120 (Continuous) & -- & 1 & \multirow{5}{*}{$\begin{array}{l}25 \% \mathrm{~N}_{2} \\
25 \% \mathrm{H}_{2} \\
50 \% \mathrm{Ar}\end{array}$} & \multirow{5}{*}{$\begin{array}{l}33 \% \mathrm{H}_{2} \\
67 \% \mathrm{Ar}\end{array}$} \\
\hline 2P1010 & 10 & 10 & 6 & & \\
\hline $2 \mathrm{P} 0515$ & 5 & 15 & 6 & & \\
\hline $2 \mathrm{P} 0218$ & 2 & 18 & 6 & & \\
\hline 2P0119 & 1 & 19 & 6 & & \\
\hline
\end{tabular}


$(\alpha)$. Since the value was obtained mathematically, the result is reported with the same number of significant digits of the austenite peak corresponding angle.

$$
a \gamma_{N}=a \gamma+\alpha C_{N}
$$

\section{Results and Discussion}

Figure 2 shows the diffractograms for treated specimens, as well as for the as-received material (SC). Only higher intensity peaks were considered.

The expanded austenite phase $\left(\mathrm{\gamma}_{\mathrm{N}}\right)$ was the only phase identified for all processing conditions. When compared to regular austenite $(\mathrm{\gamma})$, the peaks of expanded austenite $\left(\mathrm{\gamma}_{\mathrm{N}}\right)$ are broader and shifted to lower diffraction angles. This effect is caused by the presence of nitrogen in solid solution ${ }^{22}$. Based on that and on the diffractograms, it can be concluded that the amount of nitrogen dissolved in the expanded austenite phase varies according the treatment condition. It can also be inferred that as the time of nitrogen pulse decreases, the amount of nitrogen in the expanded austenite decreases as well. Even though chromium compounds have not been identified by XRD, darker areas can be seen in the micrographs shown in Figure 3. These darker areas surrounding grain boundaries (see arrows in the Figures) were observed for all treatment conditions, and have already been reported in previous work ${ }^{9}$. They correspond to regions where etching was more intense, which is consistent with the presence of chromium precipitates $\left(\mathrm{CrN}\right.$ or $\left.\mathrm{Cr}_{2} \mathrm{~N}\right)$ in these areas ${ }^{9}$. It is believed that the amount and/or size of such precipitates are below the detection limits of the XRD apparatus. EDS analyses support this hypothesis. Figure 4 shows the EDS results for the sample processed according to condition 2C. Even though this analysis is qualitative, considering the main elements of the alloy, a higher amount of chromium, when compared to the material matrix, was observed in the region where precipitation occurred.

As long as the time of nitrogen flow (nitrogen on) decreases, precipitation also decreases. For specimens treated according to condition P0119, the darker aspect around grain boundaries, which indicates precipitation of chromium compounds, was only observed at higher magnifications (Figure 3e). The tendency to reduce the amount of precipitation for shorter nitrogen pulses times, as well as the lower nitrogen saturation in austenite, was expected, since the nitrogen potential in the nitriding atmosphere is decreased ${ }^{19,20}$. However, it was observed that, even for the lowest nitrogen potential condition, the formation of chromium-based nitrides wasn't completely inhibited. Thus, one can conclude that the nitriding temperature is a major factor concerning precipitation of such compounds, regardless the nitrogen concentration in the nitriding atmosphere. Elements $\mathrm{Cr}$ and $\mathrm{N}$ have high chemical affinity, with a very negative enthalpy of formation, and the processing temperature provides enough activation energy for the reaction to occur, even if the nitrogen concentration in the atmosphere is low.

From the results of the diffractograms shown in Figure 2, it was possible to determine the lattice parameter of regular

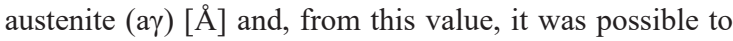
calculate the theoretical concentration of nitrogen in the expanded austenite $\left(\mathrm{C}_{\mathrm{N}}\right)$ [at $\%$ ] by using Equation 1. Obtained results are summarized in Table 3. For the as-received condition, the calculated lattice parameter was $3.59 \AA$, which is similar to the value provided by the JCPDS-ICDD ${ }^{23}$ database for austenite $(3.60 \AA)$. This value is in agreement with the low initial nitrogen content of the material $(0.077 \mathrm{wt} \%)$.

As expected, the higher incorporation of nitrogen into expanded austenite was observed for treatment with continuous nitrogen flow (condition 2C). Calculated value was 37.14 [at $\%$ ]. For a treatment of 3 hours, Gontijo et al. ${ }^{24}$ measured the nitrogen concentration by means of WDS and reported a value of 35.9 [at \%], which is very close to the value found in the present work. However, Tschiptschin and Pinedo ${ }^{25}$ reported a value of 45 [at $\%$ ]. This higher nitrogen concentration is due to the longer processing time (12 hours).

Considering treatments with intermittent nitrogen flow, the nitrogen concentration in expanded austenite varied from 26.69 [at $\%$ ] for $2 \mathrm{P} 1010$ condition to 19.99 [at $\%$ ] for condition $2 \mathrm{P} 0119$. The nitrogen concentration decreased as the time of nitrogen flow (nitrogen on time) decreased, and this is directly related to the reduction in the nitrogen potential caused by shorter time of nitrogen flow. Similar behavior was observed in the work of Tschiptschin and Pinedo ${ }^{25}$, where a lower incorporation of nitrogen was observed for lower concentration of this element in the nitriding atmosphere.

As can be observed in Figure 3, a surface layer constituted by two different regions, known as double layer, can be clearly seen for all treatment conditions. This morphology is similar to that reported by Czerwiec et al. ${ }^{26}$, where the outer layer was identified as nitrogen expanded austenite $\left(\mathrm{x}_{\mathrm{N}}\right)$, and the inner layer was identified as carbon expanded austenite $\left(\mathrm{y}_{\mathrm{C}}\right)$. According to Czerwiec et al. ${ }^{26}$, the carbon from the contamination of the plasma reactor walls causes the formation of the carbon expanded austenite $\left(\mathrm{y}_{\mathrm{C}}\right)$. This

Table 3. Lattice parameters and nitrogen concentrations.

\begin{tabular}{ccc}
\hline Condition & $\left(a \gamma_{N}\right)[\AA]$ & $\left(C_{N}\right)[\mathrm{at} \%]$ \\
\hline $2 \mathrm{C}$ & 3.88 & 37.14 \\
\hline $2 \mathrm{P} 1010$ & 3.80 & 26.69 \\
\hline $2 \mathrm{P} 0515$ & 3.80 & 26.69 \\
\hline $2 \mathrm{P} 0218$ & 3.79 & 25.56 \\
\hline $2 \mathrm{P} 0119$ & 3.75 & 19.99 \\
\hline
\end{tabular}

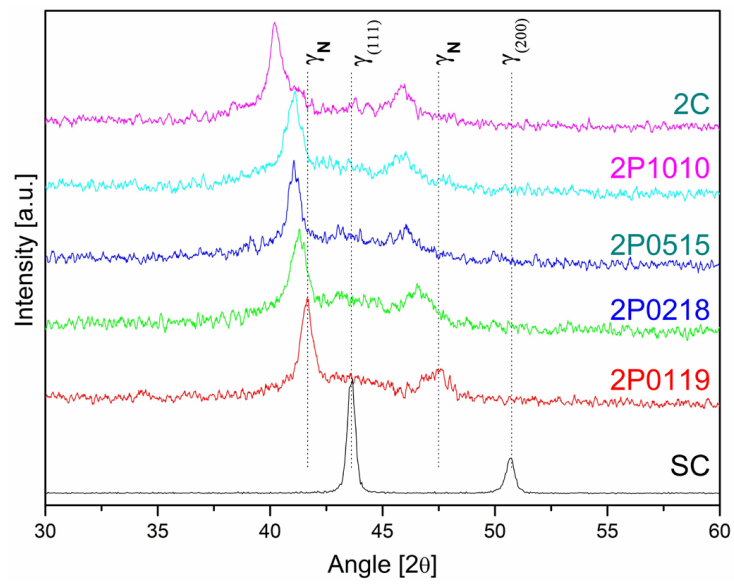

Figure 2. Diffractograms of as-received and nitrided specimens. 


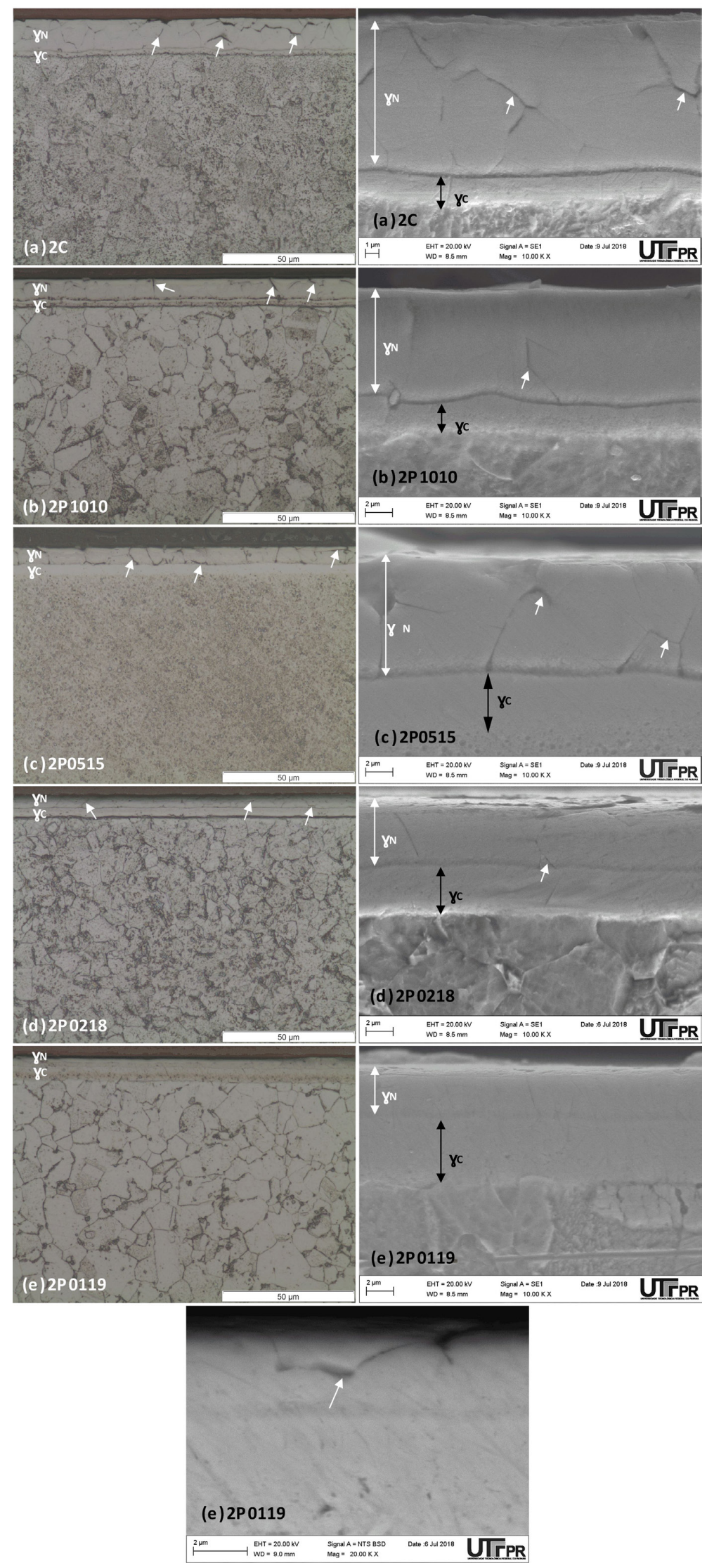

Figure 3. Micrographs of treated specimens. (a) 2C, (b) 2P1010, (c) 2P0515, (d) 2P0218, (e) 2P0119. 


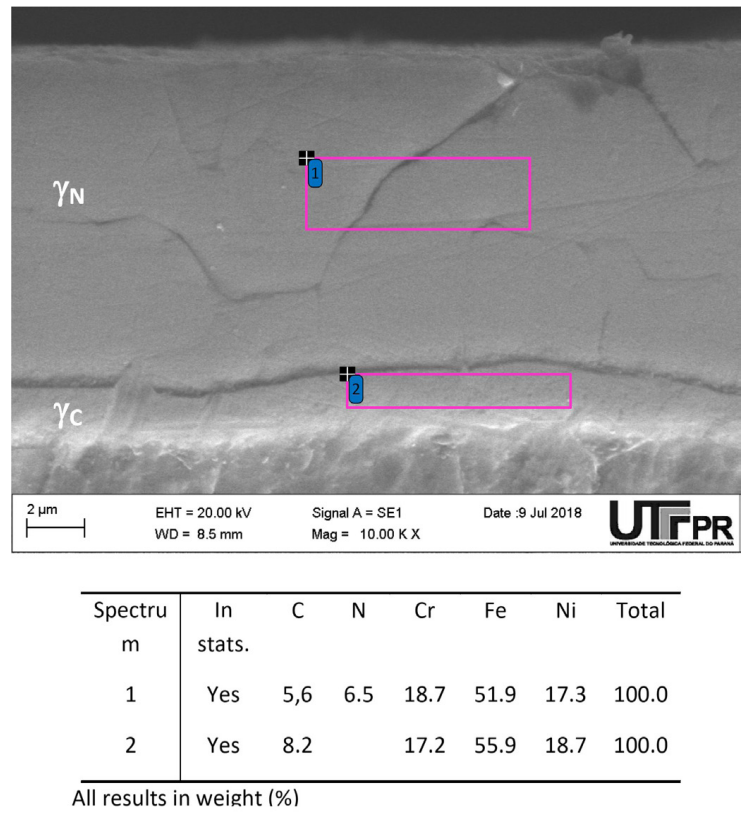

Figure 4. EDS results at grain boundaries and matrix. Processing condition: $2 \mathrm{C}$.

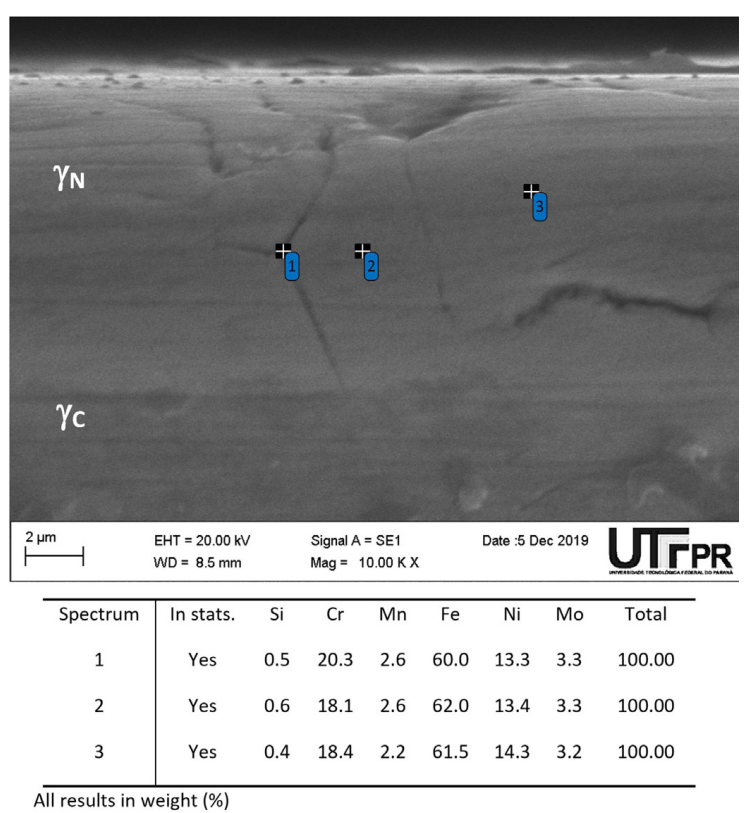

Figure 5. EDS results from regions of $\gamma_{\mathrm{N}}$ and $\gamma_{\mathrm{C}}$ layers. Processing condition: $2 \mathrm{C}$.

carbon is released during the first treatment stage (cathodic sputtering cleaning).

Figure 5 shows the results obtained by EDS for sample 2C. Although this technique is not effective to quantify both carbon and nitrogen amounts, a qualitative analysis was made in order to confirm the formation of the double layer. It was evidenced that the outer layer is rich in nitrogem $\left(\mathrm{y}_{\mathrm{N}}\right)$, while in the inner layer the carbon concentration is higher $\left(\mathrm{\gamma}_{\mathrm{C}}\right)$. In the work of Sphair ${ }^{18}$, who used the same processing conditions, besides temperature $\left(400^{\circ}\right)$, used
Table 4. Nitrided layers thicknesses (confidence interval: 95\%).

\begin{tabular}{cccc}
\hline Condition & Layer $\gamma_{\mathrm{N}}[\mu \mathrm{m}]$ & Layer $\gamma_{\mathrm{C}}[\mu \mathrm{m}]$ & $\begin{array}{c}\text { Total }\left(\gamma_{\mathrm{N}}+\gamma_{\mathrm{C}}\right) \\
{[\mu \mathrm{m}]}\end{array}$ \\
\hline 2C & $11.8 \pm 0.3$ & $2.2 \pm 0.3$ & $14.0 \pm 0.4$ \\
\hline 2P1010 & $8.5 \pm 0.2$ & $2.6 \pm 0.2$ & $11.1 \pm 0.2$ \\
\hline 2P0515 & $7.7 \pm 0.3$ & $3.3 \pm 0.3$ & $11.1 \pm 0.3$ \\
\hline 2P0218 & $3.3 \pm 0.4$ & $3.5 \pm 0.3$ & $6.9 \pm 0.3$ \\
\hline 2P0119 & $2.0 \pm 0.1$ & $4.6 \pm 0.3$ & $6.6 \pm 0.2$ \\
\hline
\end{tabular}

in the present work (2C), a quantitative analysis by means of GDOS was carried out. Concentrations of 20 [at $\%$ ] of nitrogen in the $\gamma_{N}$ layer and $0.1[a t \%]$ in the $\gamma_{C}$ layer were reported in thath work.

As shown in Table 4, the thicknesses of $\gamma_{\mathrm{N}}$ and $\gamma_{\mathrm{C}}$ layers, and consequently the total layer thicknesses $\left(\gamma_{N}+\gamma_{C}\right)$, changes according to the treatment conditions.

The layer thickness for the continuous nitrogen flow condition (2C) was $14.0 \mu \mathrm{m}$, which is in agreement with that obtained by Liang ${ }^{11}$ for AISI 304 steel in similar treatment conditions. Liang ${ }^{11}$ reported a layer thickness of $20 \mu \mathrm{m}$ (treatment temperature of $465^{\circ} \mathrm{C}$ ). The thinner layer obtained in the present work is due to the lower treatment temperature $\left(450{ }^{\circ} \mathrm{C}\right)$ and to the different chemical compositions of the materials used in both works. The molybdenum concentration is higher for the ISO 5832-1 steel, which increases nitrogen solubility and decreases its diffusion coefficient when compared to AISI 304 steel$^{9}$.

From data shown in Table 4, it can be observed that the the lower time of nitrogen flow on, the smaller the thickness of $\gamma_{N}$ layer and the overall layer thickness. This behavior is also associated to the reduction in the nitrogen potential in the atmosphere, which reduces the nitrogen available for diffusion, which is in agreement with the work of Menthe and $\mathrm{Rie}^{27}$. They studied the effect of the gaseous mixture and found that lower nitrogen concentrations in the atmosphere lead to the formation of thinner layers. Exceptions are conditions 2P1010 and 2P0515, where the total layer thickness remained constant. However, differences in thickness for $\gamma_{N}$ and $\gamma_{C}$ layers were observed: $\gamma_{N}$ layer thickness tends to decrease, while $\gamma_{C}$ layer thickness tends to increase. Similar results regarding nitriding of ISO $5832-1$ steel at $400{ }^{\circ} \mathrm{C}$ with intermittent flow of nitrogen were reported by Sphair ${ }^{18}$.

The increase in thickness of $\gamma_{C}$ layer (Table 4) that occurs as long as the nitrogen flow (nitrogen on) decresces indicates that this layer grows during nitriding, particularly while nitrogen flow is off. When the nitrogen flow is off, the argon present in the nitriding atmosphere pulls off the carbon from contamination that is stuck in the reactor walls. Carbon reaches the material surface and then diffuses to the inner layer. On the other hand, when nitrogen flow in on, free carbon reacts with nitrogen, forming $\mathrm{CN}$, which is removed from the reactor by the vacuum system. Such results are in agreement with those reported by Czerwiec et al. ${ }^{26}$ and Sphair ${ }^{18}$.

Because of the small thickness of the formed layers, it wasn't possible to measure their hardness in the longitudinal section. Hence, surface hardness was measured (Table 5), even though the layer thickness was not enough to comply with the ASTM Standard ${ }^{28}$. Since the thickness of the layer affects the hardness measurement, and the measured values 
Table 5. Surface hardness of treated specimens (confidence interval: $95 \%$ ).

\begin{tabular}{cc}
\hline Condition & $\mathrm{HV}_{0,1}$ \\
\hline $2 \mathrm{C}$ & $1286 \pm 42$ \\
\hline $2 \mathrm{P} 1010$ & $888 \pm 37$ \\
\hline $2 \mathrm{P} 0515$ & $847 \pm 16$ \\
\hline $2 \mathrm{P} 0218$ & $539 \pm 14$ \\
\hline $2 \mathrm{P} 0119$ & $417 \pm 07$ \\
\hline
\end{tabular}

result from the interaction between the layer and the material substrate, higher hardness values are obtained for thicker layers. However, considering the specific subject of this work, it is believed that the hardness fraction due to the substrate is smaller than the increase in hardness caused by the presence of nitrogen in S-phase or the presence of chromium nitrides. When comparing to the results reported by Sphair $^{18}$, who measured the hardness of nitrided layers with similar thickness by means of nanoindentation for specimens of ISO $5832-1$ steel treated at $400{ }^{\circ} \mathrm{C}$, it is observed that the hardness measurements reported in the present work were affected by the substrate. This effect increases when the layer thickness decreases.

Surface hardness increased for all treatment conditions. The highest hardness $(1286 \mathrm{HV})$ was obtained for continuous processing condition (2C). In this case, the surface hardness increased six fold when compared to as-received specimens. This value is close to that obtained by Gontijo et al. ${ }^{29}$, who reported a surface hardness of $1240 \mathrm{HV}$ for AISI 304 steel treated in similar conditions. Mendes et al. ${ }^{4}$ also got a comparable result (1343 HV) for AISI 316L sintered steel. Such surface hardening is due to residual stresses resulting from stacking faults ${ }^{30,31}$ that are associated do nitrogen supersaturation.

The layer thickness decreased with shorter times of nitrogen flow (nitrogen on), and the same behavior was observed regarding surface hardness, as shown in Table 5. This happens because of the changes in nitrogen potential, as discussed previously. Higher nitrogen potentials lead to more expansion of austenite and more precipitation of chromium nitrides, increasing surface hardness (see Table 3 ). Menthe and $\mathrm{Rie}^{27}$ also observed a decrease in surface hardness for atmospheres with low nitrogen concentration, which corresponds to a condition of short pulse of nitrogen. The lowest hardness value was obtained for the condition 2P0119; however, it was approximately twice as high as the as-received material hardness.

Based on the previous discussions, it is observed that the greatest effect of the use of intermittent nitrogen flow is related to variation of the nitrogen potential of the atmosphere. Such variation is directly related to characteristics such as layer thickness and hardness, the nitrogen saturation level of the expanded austenite, and the amount of chromium nitrides in the nitrided layer.

\section{Conclusions}

The use of intermittent nitrogen flow didn't inhibit completely the precipitation of chromium nitrides; however, it was verified that the proposed nitriding method is effective regarding the possibility of controlling both thickness and hardness of the nitrided layer, as well as the amount of nitrogen dissolved in the expanded austenite phase (S-phase). The higher the time of nitrogen flow (nitrogen on), the higher the thickness and hardness of the nitrided layer and the more expanded is the austenite of the layer.

\section{Acknowledgements}

The authors would like to thank Villares Metals for the donation of the material employed in the research, Araucaria Foundation for scientific initiation scholarship, and CNPq for financial support (CNPq Project 430088/2016-7), and Multi-User Center for Materials Characterization - CMCM of UTFPR-CT.

\section{References}

1. Larisch B, Brusky U, Spies HJ. Plasma nitriding of stainless steels at low temperatures. Surf Coat Tech. 1999;116-119:20511. http://dx.doi.org/10.1016/S0257-8972(99)00084-5.

2. Menthe E, Bulak A, Olfe J, Zimmermann A, Rie KT. Improvement of the mechanical properties of austenitic stainless steel after plasma nitriding. Surf Coat Tech. 2000;133-134:259-63. http:// dx.doi.org/10.1016/S0257-8972(00)00930-0.

3. Olzon-Dionysio M, Campos M, Higa OZ, Cunha TF, Souza SD. Investigating the correlation between some of the properties of plasma nitrided AISI 316L stainless steel. Mater Res. 2013;16(5):1052-7. http://dx.doi.org/10.1590/S151614392013005000081.

4. Mendes AF, Scheuer CJ, Joanidis IL, Cardoso RP, Mafra M, Klein NA, et al. Low-temperature plasma nitriding of sintered PIM 316L austenitic stainless steel. Mater Res. 2014;17(Supl. 1):100-8. http://dx.doi.org/10.1590/S1516-14392014005000064.

5. Abreu CM, Cristóbal MJ, Merino P, Nóvoa XR, Pena G, Pérez MC. Electrochemical behaviour of an AISI 304L stainless steel implanted with nitrogen. Electrochim Acta. 2008;53(20):6000-7. http://dx.doi.org/10.1016/j.electacta.2008.03.064.

6. Garzón CM, Tschiptschin AP. Nitretação em alta temperatura de aços inoxidáveis. Matéria [serial on the Internet]. 2005 [cited 2019 Sep 3];10(4):502-25. Available from: http://www. materia.coppe.ufrj.br/sarra/artigos/artigo10697

7. Reis RF, Maliska AM, Borges PC. Nitrogen surface enrichment of austenitic stainless steel ISO 5832-1. J Mater Sci. 2011;46(3):84654. http://dx.doi.org/10.1007/s10853-010-4827-3.

8. Borges PC, Rocha LA. Solution heat treatment of plasma nitrided 15-5PH stainless steel - Part I: improvement of the corrosion resistance. Kovové Materiály. 2011;49(2):107-17. http://dx.doi.org/10.4149/km_2011_2_107.

9. Reis RF, Villanova RL, Costa KD, Durante GC. Nitrogen surface enrichment of austenitic stainless steel ISO 5832-1: SHTPN vs Low-temperature plasma nitriding. Mater Res. 2015;18(3):57580. http://dx.doi.org/10.1590/1516-1439.352014.

10. Liang W, Juncai S, Xiaolei X. Low pressure plasma arc source ion nitriding compared with glow-discharge plasma nitriding of stainless steel. Surf Coat Tech. 2001;145(1-3):31-7. http:// dx.doi.org/10.1016/S0257-8972(01)01283-X.

11. Liang W. Surface modification of AISI 304 austenitic stainless steel by plasma nitriding. Appl Surf Sci. 2003;211(1-4):308-14. http://dx.doi.org/10.1016/S0169-4332(03)00260-5.

12. Gavriljuk V, Berns H. High nitrogen steels. Berlin: SpringerVerlag; 1999. http://dx.doi.org/10.1007/978-3-662-03760-7.

13. Picard S, Memet JB, Sabot R, Grosseau-Poussard JL, Rivière JP, Meilland R. Corrosion behaviour, microhardness and surface characterisation of low energy, high current ion implanted 
austenitic stainless steel. Mater Sci Eng A. 2001;303(1-2):16372. http://dx.doi.org/10.1016/S0921-5093(00)01841-4.

14. Xi YT, Liu DX, Han D. Improvement of mechanical properties of martensitic stainless steel by plasma nitriding at low temperature. Chin Shu Hsueh Pao. 2008;21:21-9. http://dx.doi.org/10.1016/ S1006-7191(08)60015-0.

15. Bernardelli EA, Borges PC, Fontana LC, Floriano JB. Role of plasma nitriding temperature and time in the corrosion behaviour and microstructure evolution of 15-5 PH stainless steel. Kovové Materiály. 2010;48(2):105-16. http://dx.doi. org/10.4149/km_2010_2_105.

16. Stinville JC, Villechaise P, Templier C, Riviere JP, Drouet M. Plasma nitriding of $316 \mathrm{~L}$ austenitic stainless steel: experimental investigation of fatigue life and surface evolution. Surf Coat Tech. 2010;204(12-13):1947-51. http://dx.doi.org/10.1016/j. surfcoat.2009.09.052.

17. Baranowska J, Arnold B. Corrosion resistance of nitrided layers on austenitic steel. Surf Coat Tech. 2006;200(22-23):6623-8. http://dx.doi.org/10.1016/j.surfcoat.2005.11.099.

18. Sphair AC. Nitretação por plasma de aço inoxidável austenítico com fluxo pulsado de nitrogênio [dissertação]. Curitiba: Programa de Pós-graduação em Engenharia Mecânica e de Materiais, Universidade Tecnológica Federal do Paraná; 2017.

19. Yazıcı M, Çomaklı O, Yetim T, Yetim AF, Çelik A. The effect of plasma nitriding temperature on the electrochemical and semiconducting properties of thin passive films formed on $316 \mathrm{~L}$ stainless steel implant material in SBF solution. Surf Coat Tech. 2015;261:181-8. http://dx.doi.org/10.1016/j.surfcoat.2014.11.037.

20. Mingolo N, Tschiptschin AP, Pinedo CE. On the formation of expanded austenite during plasma nitriding of an AISI 316L austenitic stainless steel. Surf Coat Tech. 2006;201(7):4215-8. http://dx.doi.org/10.1016/j.surfcoat.2006.08.060.

21. International Organization for Standardization. Implants for sugery: metallic materials: part 1: wrought stainless steel. Geneva: ISO; 2016.

22. Campos M, Souza SD, Martinez LG, Olzon-Dionysio M. Study of expanded austenite formed in plasma nitride AISI $316 \mathrm{~L}$ samples, using synchrotron radiation diffraction. Mater Res. 2014;17(5):1302-8. http://dx.doi.org/10.1590/1516-1439.285914.

23. ICDD. (2012). ICDD PDF-2 Release 2012 (Database), edited by Dr. Soorya Kabekkodu, International Centre for Diffraction Data, Newtown Square, PA, USA.

24. Gontijo LC, Machado R, Miola EJ, Casteletti LC, Alcântara NG, Nascente PAP. Study of the $\mathrm{S}$ phase formed on plasma-nitrided AISI 316L stainless steel. Mater Sci Eng A. 2006;431(1-2):31521. http://dx.doi.org/10.1016/j.msea.2006.06.023.

25. Tschiptschin AP, Pinedo CE. Estrutura e propriedades do aço inoxidável austenítico AISI 316L grau ASTM F138 nitretado sob plasma à baixa temperatura. Rev Min Enferm. 2010;63(1):13741. http://dx.doi.org/10.1590/S0370-44672010000100023.

26. Czerwiec T, He H, Weber S, Dong C, Michel H. On the occurrence of dual diffusion layer during plasma-assisted nitriding of austenitic stainless steel. Surf Coat Tech. 2006;200(18-19):528995. http://dx.doi.org/10.1016/j.surfcoat.2005.06.014.

27. Menthe E, Rie K-T. Further investigation of the structure and properties of austenitic stainless steel after plasma nitriding. Surf Coat Tech. 1999;116-119:199-204. http://dx.doi.org/10.1016/ S0257-8972(99)00085-7.

28. American Society for Testing and Materials. ASTM E384: standard test method for knoop and vickers hardness of materials. West Conshohocken: ASTM; 2011. http://dx.doi.org/10.1520/ E0384-11E01.

29. Gontijo LC, Machado R, Casteletti LC, Kuri SE, Nascente PAP. Comparação entre os comportamentos dos aços inoxidáveis AISI 304L e AISI 316L nitretados a plasma. Rev Bras Apl Vácuo [serial on the Internet]. 2007 [cited 2019 Sep 3];26(3):145-50. Available from: www.sbvacuo.org.br/rbav/index.php/rbav/ article/download/37/35

30. Christiansen T, Somers MAJ. On the crystallography structure of S-phase. Scr Mater. 2004;50(1):35-7. http://dx.doi.org/10.1016/j. scriptamat.2003.09.042.

31. Tuckart W, Forlerer E, Iurman L. Delayed cracking in plasma nitriding of AISI 420 stainless steel. Surf Coat Tech. 2007;202(1):199202. http://dx.doi.org/10.1016/j.surfcoat.2007.04.107. 